\title{
PORTRAITS AND POLITICS: THE SPECTER OF OSCEOLA IN LEAVES OF GRASS
}

\author{
KATHRYN WALKIEWICZ
}

ONE OF THE FEW IMAGES to hang in the second floor room of the Camden home where Whitman spent a great deal of time in his last years was a famous George Catlin lithograph of Osceola. It was a portrait, allegedly given to him by the artist, that had been "packed away for a good many years" before being placed on his wall. When Whitman uncovered the piece- "torn, cracked and frayed" - he "spent an hour one day in piecing it and pasting it on that paper." The image of Whitman carefully repairing the fractured portrait of the famous Seminole fighter is a peculiar one. Whitman was not known for his cleanliness or tidiness, so taking the time to painstakingly restore the lithograph, as if piecing together a puzzle, might seem both unusual and out of character. Nonetheless, I would argue that his effort to reconstruct the portrait of the famous Native American leader is in keeping with his beliefs about the role of Native Americans in the United States. The restoration indicates his desire to make the image once again a cohesive whole, a finite representation of Seminole insurgence during the Indian Removal era of the nineteenth century. The action seems fitting if one understands it as both a literal and symbolic attempt to control and contain representations of an American past that belie the nation's violent imperialist projects. Like a ghost, the image literally returns to remind Whitman of Osceola, Indian Removal, and the underbelly of American exceptionalism.

It is striking that in describing to Horace Traubel the writing of his poem "Osceola," Whitman uses the same language of piecing together a kind of puzzle and explicitly associates the writing of the poem with the reconstructed portrait: "So today I set to work-pieced a poem'Osceola'-the Indian chief across there," he tells Traubel, while "pointing to the old lithograph tacked on the wall opposite."2 We will see just how much piecing and pasting was in fact involved in his composition of the poem.

"Osceola" was first published in the April 1890 issue of Munyon's Illustrated World afterWhitman promised its editor, Melville Phillips, that he would try to come up with a "little poem or poems" for the magazine ( $W W C$ 6:266). The piece would later be included in the "Second Annex" section in Leaves of Grass. The epigraph of the poem details its supposed 
inspiration: "When I was nearly grown to manhood in Brooklyn, New York, (middle of 1838, I met one of the return'd U. S. Marines from Fort Moultrie, S. C., and had long talks with him-learn'd the occurrence below described-death of Osceola." ${ }^{3}$

In describing the painting's context to Horace Traubel and J. Johnston, Whitman describes Osceola as "in our early history, you knowtaken prisoner-died in prison from confinement" (WWC 6:266). He emphasized Osceola's status as a mixed-blood warrior who was "basely betrayed, imprisoned, and literally done to death" by United States troops during the Second Seminole War (Johnston 54). Whitman's depiction of him follows the stock narrative that was popular both during Osceola's life and following his death. While alive, Osceola was represented, in Euroamerican print culture, as a Robin Hood of sorts, whose name became synonymous with the successes of Seminole resistance in Florida. His popularity rose when his frustrations with General Wiley Thompson's treaties and negotiations led not only to his refusal to sign a treaty moving the Seminole Nation to Indian Territory, but to his dramatic stabbing of the treaty with his knife. It was Osceola's death, however, that brought him the greatest fame and iconic status. He was seen as a martyr, a figure of rebel resistance, not unlike a American revolutionary patriot, fighting for freedom and sovereignty. Such mythic status, however, was problematic, because it challenged the ethicality of American expansion; if Osceola and the Seminoles were the heroes, then the United States army was ... something else. Because of this, the rhetoric of American exceptionalism had a vested interest in controlling Osceola's image, which was why so much emphasis was placed on his imprisonment and death at Fort Moultrie in South Carolina. Once he was incarcerated and no longer an active physical threat, his symbolic threat to American expansion and Manifest Destiny could be assuaged, and his status as a "wild Indian" constructed, controlled, and made marketable. He could at that point become the "vanishing Indian," the symbol of a culture and a people that must sadly but inevitably disappear in the wake of expansion.

Whitman participates in this same articulation of Osceola in his poem. He recounts the man's death - not his life-in an attempt to justify large-scale United States military invasions and genocidal projects like that of the Second Seminole War, while also denying a continued Seminole presence, a living and thriving Seminole people. However, Whitman is also haunted by the void and lack that such a limited articulation leaves. His painstaking work to refigure and reconstruct the lithograph of Osceola simultaneously asserts his investment in the consumable, controlled Euroamerican image of Osceola, as well as his awareness that it is, in fact, a consciously crafted construction. 
Horace Traubel describes a conversation on May 11, 1890, in which Whitman explains that he learned from "Osceola's surgeon ... that he [Osceola] literally died of a broken heart - died of the confinement, imprisonment." During the same conversation, Whitman also tells Traubel, "The poem is given almost word for word out of conversations I have had with Catlin: Catlin, the great Indian man" (WWC 6:400). It seems likely that Whitman pulled his information from a source that would more or less make both these assertions true, Catlin's Letters and Notes on the Manners, Customs, and Condition of the North American Indians, with which he was quite familiar. Catlin claims his account of Osceola's death (included in a footnote) "was furnished me by Dr. [Frederick] Weedon, the surgeon who was by him" during his last days. ${ }^{4}$ In addition to recreating Catlin's portrait, Whitman's poem reconstructs Osceola's deathbed monologue, almost verbatim, as told by Weedon and recorded by Catlin. Whitman writes: "He slowly rais'd himself from the bed on the floor, / Drew on his war-dress, shirt, leggings, and girdled the belt around his waist" ( $L G 550)$. Catlin writes:

He made signs to his wives (of whom he had two, and also for two fine little children by his side,) to go and bring his full dress, which he wore in time of war; which having been brought in, he rose up in his bed, which was on the floor, and put on his shirt, his leggings and moccasins - girded on his war-belt-his bullet-pouch and powder-horn, and laid his knife by the side of him on the floor. (221)

\section{Whitman writes:}

Call'd for vermilion paint (his looking-glass was held before him,)

Painted half his face and neck, his wrists, and back-hands,

Put the scalp-knife carefully in his belt-then lying down, resting a moment,

Rose again, half sitting, smiled, gave in silence his extended hand to each and all,

Sank faintly low to the floor (tightly grasping the tomahawk handle,)

Fix'd his look on wife and little children-the last:

(And here a line in memory of his name and death.) (LG 550-551)

\section{Catlin narrates the event, as Weedon had told it to him:}

He then called for his red paint, and his looking-glass, which was held before him, when he deliberately painted one half of his face, his neck, and his throat - his wrists - the backs of his hands, and the handle of his knife, red with vermilion; a custom practiced when the irrevocable oath of war and destruction is taken [. . . he laid down a few minutes to recover strength sufficient, when he rose up as before, and with most benignant and pleasing smiles, extended his hand to me and to all of the officers and chiefs that were around him; and shook hands with us all in dead silence; and also with his wives and little children. (221-222) 
The similarity between the two narratives is uncanny and undeniable.

If, in fact, Whitman did use this footnote as the key textual source for his poem, it adds yet another layer of transcription to the account, throwing its factual verity into further doubt as the number of mediating consciousnesses proliferate. The confusion surrounding the story's origins and authenticity is ironically consistent with the misrepresentations many historians and commentators have used to articulate Osceola and the Second Seminole War (1835-1842), specifically, and Indian Removal in general. They function less as factual representations of events and people, and more as a means of disposing of social issues the wars raised in both the North and the South-white America's belief in the right to Manifest Destiny and the uncertainty that accompanied the rapid expansion of American colonialism. Many decades later, the truth, or even a semblance of truth, is still difficult to unearth. Whitman and standard U.S. histories are still unable to be honest about the fighting in Florida. Whitman's poem provides layers of narrative authority that are displaced and concealed. After all, the epigraph of the poem says nothing about Catlin or Weedon, the two most well-known observers of Osceola's death (and the obvious source of Whitman's description), further diffusing and displacing the narrative. The choice is an interesting one, indicating anxiety about attributing the scene to an artist and revealing a kind of multi-layered ventriloquism. Somehow, the narrative is more mythic if its narrator is unknown and non-descript, much like the democratic speaker in many of Whitman's other works. The speaker becomes a symbolic American, the young patriot, in a way, and obtains greater agency through this anonymity than Catlin or Weedon would. Ironically, however, the move simultaneously reveals its own anxieties about the personal and political investments embedded in his representation.

As with most Euroamerican translations of Native-white contact, there is a great deal of skepticism surrounding the validity of the deathbed narrative endorsed so emphatically by Weedon, Catlin, and finally Whitman. One source claimed that Osceola requested a medicine man instead of Weedon, possibly because of Osceola's prior connection to the white doctor: he had killed Weedon's brother-in-law Wiley Thompson, a fact both men were aware of. ${ }^{5}$ While this information is rarely included in the narrative of Osceola's final days, it would certainly have complicated the doctor-patient relationship. Even if his relationship to the doctor was nothing more than a bizarre coincidence, records of Osceola's concerns while at Fort Moultrie make the romantic narration of his last days suspect and reinforce the textual agency men like Weedon and Catlin desired - by silencing his own narrative, theirs could then come to life. Like the deathmask cast after Osceola's passing (at Weedon's request), 
the narrative, painting, and poem attempt to shape him into something consumable, non-threatening and, most importantly, of the past. ${ }^{6}$

As John and Mary Lou Missal note: "The Second Seminole War was forgotten almost as soon as it ended. There were no banner headlines, no parades for the returning victors, and very little reflection upon what may have been learned. It had been an unpopular, dirty little war, and no one wanted to talk about it." Despite efforts to forget the conflict, "for many Americans the war could not be forgotten. Thousands of people were forced to live with the emotional and physical scars that had been dealt out over seven years of desperate conflict." "Whitman's careful preservation of the lithograph and his inclusion of "Osceola" in the sixth edition of Leaves of Grass, decades after the conflict, reinforces the war's persistence in the minds of citizens who lived through it; these memories displayed a powerful ability to resurface despite efforts to bury them.

In Walt Whitman's Native Representations, Ed Folsom discusses the complex and often contradictory relationship Whitman had with Native American identity. Folsom asserts that Whitman believed that a sense of Native, indigenous identity separate from the United States must be eliminated in order to create a more cohesive nation: "to give Indians a line in the song of America seemed to be Whitman's continual motivation, to absorb them into the American song before they vanish forever, to preserve them in English words." "Whitman tries to restrict Native identity to the static two-dimensional page, continuing to see Native identity only in relation to his own life and to Euroamerica. Doing so allows white men, like Whitman, to control and constrain depictions of Native identity. It ensures that their memory (Whitman almost always saw Native American identity in the past tense) is preserved in English, the language of Whitman's America, the colonizer.

Further troubling this agenda, however, is Whitman's unease with his own reputation. At the time Whitman writes of Osceola, he too is in physical decline, often confined indoors, as he lives out his last years in Camden. Folsom argues that a return to Osceola is a return to a representation of a death that, perhaps, Whitman hopes to re-cite and appropriate for his own eulogy. While Folsom sees the last line of the poem as a "late acknowledgement of white betrayal of Indians" (77), I would argue that it also reveals Whitman reading himself into the image of Osceola. The space the last line leaves open for a response from Osceola mirrors Whitman's concerns about how his own image would be re-presented after his death.

Folsom discusses Whitman's fascination with photography as the desire to possess a kind of postmortem agency through his portraits and his poetry: "Just as he intensifies the effect of many of his poems by addressing them to readers who will be reading them long after the poet 
is dead, so does he use his portraits to add to the sense of a conquering of space and time" (138). Whitman's poem does not express regret or seek reparations for crimes committed against Native people, but rather expresses concern that his own identity can be as easily translated and erased as that of Osceola. Thus Whitman's poem does not simply recall the myth of Osceola but rather works to propel the poet's understanding of Native Americans and American identity into the future. In an ironic twist, three days after Whitman submitted the poem to Munyon's, "Philips and two photographers" came to take photographs for the magazine, linking the poet's portrait to that of Osceola. ${ }^{9}$ Whitman, perhaps unsurprisingly, was not pleased with the photograph taken for the magazine - he wanted to use an image of his own choosing. ${ }^{10}$

His poem continues to reinforce another footnote about the Second Seminole War in Catlin's Letters and Notes on the Manners, Customs, and Condition of the North American Indian: "The world will pardon me for saying no more of this inglorious war, for it will be seen that I am too near the end of my book to afford it the requisite space; and as an American citizen I would pray, amongst thousands of others, that all books yet to be made might have as good an excuse for leaving it out" (219). Whitman's ability to construct Osceola cannot extend to the conflict the Seminole chief initially represented because it would indict Whitman and the United States in the project of American colonialism. As Louis Owens explains, Native people must be "subsumed and erased in a strange dance of repulsion and desire that has given rise to one of the longest sustained histories of genocide and ethnocide in the world as well as a fascinating drama in which the colonizer attempts to empty out and reoccupy not merely the geographical terrain but the constructed space of the indigenous Other." ${ }^{\prime 1}$ To articulate the historical moment in which Osceola achieved fame would be to conjure up the very crimes and "repulsion" the nation had worked so hard to erase from the national narrative.

For these reasons, the most intriguing line of the poem is perhaps the last: "(And here a line in memory of his name and death)." Whitman leaves the line open for Osceola to fill in. On the original manuscript, we can see that Whitman may have included a line following this but erased it, unfortunately leaving it illegible. ${ }^{12}$ What the original last line said, however, is not as important as Whitman's decision to eliminate it and leave the poem open-ended. While the rest of the poem emulates the stock narrative told about his death, the last line opens up the discourse, creates a gap for what has not been textually uttered and what will never again be-Osceola's own version of the events. It is as if the poem itself leaves a space for his ghost, and for all that was repressed during and after the war. 
Thus, Whitman attempts a democratic dialogue with Osceola the man in addition to Osceola the icon. Yet it is one that continues to fail. Osceola remains merely symbolic for Whitman - a text to read and interpret. It might be comforting to think that in Whitman's later years, after having worked in the Bureau of Indian Affairs, he had become dissatisfied with governmental Indian policy and the dangers of stereotyping Native people, but in fact the poem continues to promote the limited view of Osceola that Catlin and Weedon had endorsed. Whitman's reconstruction of the lithograph and the deathbed narrative reveal the haunting presence of the Second Seminole War, despite national attempts to elide its memory - perhaps even because of this elision. While the presence of "Osceola" in Leaves of Grass is fairly unassuming, an exploration of its historical, cultural, and political underpinnings helps illuminate the poem's unique position in Whitman's canon and troubles the ways in which we read Whitman's work. It is an invaluable testament to the powerful mark Indian Removal left on the United States, acknowledged or not, and the inability to deny the spectral presence of colonial, imperial guilt. If we unpack Whitman as icon, investigating his self-awareness as an influential, "democratic" poet, poems like "Osceola" take on a deeper meaning and reinforce the notion that the appropriation and consumption did not leave the colonizer unscathed. It was, after all, the face of Osceola that looked out at Whitman during his last years in Camden. In piecing together Osceola's portrait, he resurrected the presence that would come back to haunt him.

Texas Tech University

\section{NOTES}

I would like to thank Jesse Alemán for his unwavering support, patience, and insight throughout the various versions of this piece.

1 J. Johnston and J.W. Wallace, Visits to Walt Whitman in 1890-1891 (New York: Egmont Arens, 1918), 54. Hereafter Fohnston.

2 Horace Traubel, With Walt Whitman in Camden, ed. Gertrude Traubel and William White (Carbondale: Southern Illinois University Press, 1982), 6:266. Hereafter $W W C$.

3 Walt Whitman, Leaves of Grass: Comprehensive Reader's Edition, ed. Harold W. Blodgett and Sculley Bradley (New York: New York University Press, 1965), 550. Hereafter $L G$. 
4 George Catlin, Letters and Notes on the Manners, Customs, and Conditions of the North American Indians (London:Tosswill and Meyers, 1841), 2:221. There has been a growing critical realization that, in composing his poems, Whitman frequently lifted phrases and images from articles and books that he read, especially in his Drum-Taps poems; see Ted Genoways, "Civil War Poems in 'DrumTaps' and 'Memories of President Lincoln,'” in Donald D. Kummings, ed., A Companion to Walt Whitman (Malden, MA: Blackwell, 2006), 526-528.

5 John Mahon, History of the Second SeminoleWar: 1835-1842 [Revised Edition] (Gainesville, University of Florida Press, 1985), 170.

6 Despite these attempts to silence Osceola, the threat he posed could never fully be quelled, as revealed in Weedon's dismemberment of the corpse. $\mathrm{He}$ decapitated the body, preserved the head, took it home, and hung it on his sons' beds when they misbehaved or displayed it in the window of his pharmacy (see Patricia R. Wickman, Osceola's Legacy [Tuscaloosa:The University of Alabama Press, 1991], 148). Weedon's violent souvenir-taking reveals another side to the story, one that continued even to Whitman's poem, for even if "the doctor and officers made allowance and kindness possible for him," as Whitman asserts, Osceola and the threat he symbolized could not be erased ( $L G 550$ ). Like Osceola's head, which continued to haunt Weedon, the wars no doubt left a mark on the national consciousness, despite attempts to forget or repress their meaning.

7 John and Mary Lou Missal, The SeminoleWars:America's Longest Indian Conflict (Gainesville: University Press of Florida, 2004), 203.

8 Ed Folsom, Walt Whitman's Native Representations (Cambridge: Cambridge University Press, 1994), 77.

9 The Correspondence, ed. Edwin Haviland Miller (New York: New York University Press, 1961), 5:23. Hereafter Corr.

10 He offered them "a big front head y'r artist might make something of it not too late-hasn't been printed at all any where" (Corr 5: 27-28).

11 Louis Owens, "As If An Indian Were Really An Indian," Native American Representations: First Encounters, Distorted Images, and Literary Appropriations, ed. Gretchen M. Bataille (Lincoln: University of Nebraska Press, 2001), 16.

12 The manuscript of "Osceola" is at Yale University's Collection of American Literature in the Beinecke Rare Book and Manuscript Library; it is reproduced and transcribed on the WaltWhitman Archive (www.whitmanarchive.org/manuscripts/transcriptions/index.html). 